\title{
Pembuatan Cairan Desinfektan dalam Peran serta Penanganan Covid-19 Berdasarkan Instruksi Presiden Nomor 4 Tahun 2020 Bersama PCM Kramat Jati dan Pemuda Muhammadiyah DKI Jakarta
}

\author{
Marjan Miharja, Wiend Sakti Myharto, Yastuty Handalya, Emil Salim, \\ Anggoro Hendrawan, Ryan Hidayat, Jean Magtel Pah, \& Mayang Maharani Yahya B. \\ Sekolah Tinggi Ilmu Hukum IBLAM
}

\begin{abstract}
Abstrak
The spread of Covid-19 has become one of the people's concerns, starting in the city of Wuhan, China at the end of 2019 when this virus was discovered, the spread of the virus that the antidote has not yet been found is now out of control. More than 200 countries in the world have reported that their people have contracted the Covid-19 virus. Corona Virus Disease 19 has been declared a Global Public Health Emergency by the World Health Organization (WHO) on January 30, 2020. Conditions in Indonesia until Thursday, November 30, 2020, the number of residents who tested positive for Covid- 19 reached 538,883 cases, 450,518 people recovered and 16,945 of them died. This figure will continue to increase in line with the opinion of some epidemiologists and statistics that a pandemic outbreak will not end quickly. The purpose of this community service activity is to realize one of the contents of Presidential Instruction Number 4 of 2020, namely "Rrefocussing activities, reallocation of budgets and procurement of goods and services in order to accelerate the handling of Corona Virus Disease 2019 (COVID19)", namely by making and distributing fluids. Disinfectant that is safe and environmentally friendly and recommended by the BPOM and the World Health Organization (WHO) to help people face the New Normal era. The result of this service activity is a disinfectant liquid that is safe and environmentally friendly and able to anticipate the spread of covid-19 and increase public awareness of the Covid-19 Virus in the face of the New Normal era.
\end{abstract}

Keywords: Community service, Covid-19, pandemic, Indonesia

\section{Pendahuluan}

Pengabdian kepada masyarakat merupakan salah satu dari Tri Dharma Perguruan Tinggi, Pengabdian Kepada Masyarakat (PKM) termasuk mata kuliah lapangan yang menitik beratkan pada kerja dan sosialisasi mahasiswa/mahasiswi dimasyarakat. Mata kuliah PKM di STIH IBLAM Jakarta mempunyai sasaran pada masyarakat yang terkena wabah pandemi COVID19.

Sesuai dengan jurusan dari Sekolah Tinggi yang kami tekuni sekarang, kami coba melihat kembali Aspek Hukum Penanganan Penyebaran Covid-19, yang mana Kesehatan adalah salah satu kebutuhan dasar manusia, yang belakangan telah dijamin haknya secara konstitusional. Melalui Perubahan Kedua Undang-Undang Dasar 1945, kesehatan ditegaskan sebagai bagian dari hak asasi manusia. Dalam Pasal 28H ayat (1) dinyatakan, bahwa: "Setiap orang berhak hidup sejahtera lahir dan batin, bertempat tinggal, dan mendapat lingkungan hidup yang baik dan sehat serta berhak memperoleh pelayanan kesehatan." Masuknya ketentuan tersebut ke dalam Undang-Undang Dasar 1945, menggambarkan perubahan paradigma yang luar biasa. Kesehatan dipandang tidak lagi sekedar urusan pribadi yang terkait dengan nasib atau karunia 
Tuhan yang tidak ada hubungannya dengan tanggung jawab negara,melainkan suatu hak hukum (legal rights) yang tentunya dijamin oleh Negara.

New normal menjadi babak baru setelah pandemi Covid-19 dimana semua pola kehidupan berubah mengikuti aturan pemerintah dengan adanya sosial distancing, dan wajib penggunakan masker bahkan ada sanksi jika aturan baru ini tidak diterapkan, karena new normal merupakan tatanan kehidupan yang baru dan harus dipatuhi demi menekan penyebaran pandemi ini. Meskipun sudah memasuki kondisi new normal, wabah ini tetap harus diwaspadai karena wabah ini diperkirakan masih akan berlanjut jika tatanan baru yang ada tidak dipatuhi. Tatanan kehidupan baru atau kenormalan baru yang harus dijalani akan berakibat makin buruk jika kita tidak taat pada protokol kesehatan yang diisyaratkan pemerintah. Dalam menghadapi kondisi new normal, perilaku dan tindakan masyarakat harus berubah total dari tindakan biasa yang sering di lakukan. Sudah banyak himbauan dari pemerintah terkait perubahan prilaku yang harus dilakukan, namun nampaknya tidak mempengaruhi semua orang secara merata. Melihat kondisi ini, tidak menyurutkan semangat untuk melakukan kegiatan pengabdian kepada masyarakat. Tim Pengabdi Kepada Masyarakat (PKM) STIH IBLAM yang diketuai oleh Dr. Marjan Miharja S.H.,M.H. melakukan kegiatan ini dengan cara membuat dan mendistribusikan produk desinfektan untuk mewujudkan salah satu isi Intruksi Presiden Nomor 4 Tahun 2020 yaitu "Refocussing kegiatan, realokasi anggaran serta pengadaan barang dan jasa dalam rangka percepatan penanganan Corona Virus Disease 2019 (COVID-19)".

Dalam pembuatan produk tersebut kami Tim Pengabdi STIH IBLAM bekerjasama dengan Mitra PCM Kramat Jati dan PWPM DKI Jakarta.

Kegiatan pertama kami adalah melakukan observasi ketempat Pemuda Muhammadiyah DKI Jakarta dengan melihat kegiatan apa saa yang bisa kami jadikan sebagai bahan PKM yang berhubungan dengan regulasi pemerintah tentang penanganan bencana COVID-19, mulai dari apa yang akan kami hasilkan, tempat pelaksanaan PKM, menganalisa kondisi lingkungan tempat mitra kami, produk yang dihasilkan, bahan bahan yang dibutuhkan, dan lainnya. Setelah melakukan observasi dan diskusi dengan pihak PCM Kramat Jati dan PWPM DKI Jakarta beserta pembimbing maka diperoleh gambaran mengenai apa yang harus kami lakukan dan akan kami gunakan dalam menyusun program kerja dan target dalam MK PKM kami, dengan tetap sesuai rencana kami membantu pemerintah dalam regulasi penanganan wabah COVID19.

Target kami dalam kegiatan PKM ini yaitu ingin membantu pemerintah dalam menurunkan menyebaran wabah pandemi,serta membantu pemerintah menumbuhkan rasa disiplin akan kebersihan diri dan lingkungan bagi masyarakat, karena kebersihan merupakan salah satu kunci untuk kita bisa melewati masa pandemi saat ini.Untuk mengembangkan usaha ini kami mengalokasikan dana mandiri kelompok kami.

\subsection{Perumusan Masalah}

a. Bagaimana membuat cairan desinfektan yang aman serta ramah lingkungan yang direkomendasikan oleh BPOM dan Organisasi Kesehatan Dunia (WHO) untuk membantu masyarakat menghadapi era New Normal?

b. Susahnya mendapatkan bahan dasar pembuatan desinfektan yang sesuai dengan kadar yang diperlukan.

c. Waktu, merupakan permasalahan kami dan mitra dalam proses pembuatan desinfektan ini. 


\subsection{Solusi Permasalahan}

Dengan permasalahan yang ada yaitu mengenai produksi pembuatan cairan desinfektan dan mengenai waktu serta bahan bahan dasar yang susah kami apatkan, maka kami mencoba berkoordinasi dengan pihak Mitra 1 PWPM DKI Jakarta mengenai jadwal yang telah kami susun untuk kegiatan PKM ini, solusi yang kami dapatkan, sebagai berikut:

a. Dengan Kepakaran yang dimiliki Mitra 1 PWPM DKI Jakarta, kami dapat membuat Desinfektan yang aman dan ramah lingkungan.

b. Berkoordinasi dengan Mitra kami PCM Kramat Jati dan PWPM DKI Jakarta Koordinasi yang dimaksud guna menyesuaikan dengan waktu yang mitra miliki agar semua jadwal dapat berjalan sesuai rencana dan kami juga dapat segera menyelesaikan tugas ini sesuai waktu yang telah ketua PKM berikan.

c. Dari beberapa solusi diatas ada target luaran yang akan kami lakukan yaitu dengan menginfokan pada masyarakat baik berupa Jurnal, video youtube maupun berita di media cetak maupun online, bahwa kami sebagai mahasiswa juga dapat memberikan sumbangsih kepada negara dan masyarakat Indonesia sesuai dengan kemampuan kami sebagai mahasiswa.

\subsection{Jenis Kepakaran yang Diperlukan}

Demi menunjang kegiatan kami, kami membutuhkan seseorang yang memiliki kepakaran yang sangat mendukung kegiatan PKM ini, kepakaran yang kami butuhkan tidak jauh dari dunia kesehatan, kepakaran yang memahami bagaimana dan apa kandungan yang benar untuk proses pembuatan Cairan Desinfektan ini. Untuk itu kami merangkul kemitraan PWPM DKI Jakarta karena mitra kami mempunyai kepakaran yang dimaksud dan memiliki kredibilitas baik yang bisa dipertanggungawabkan sehingga kami mendapatkan manfaat dari kegiatan ini dan terarah.

\subsection{Metode Pelaksanaan}

Ada beberapa permasalahan yang menjadi kendala dalam kegiatan kami salah satunya adalah waktu, maka solusi yang kami hadirkan dalam pelaksanaan kegiatan ini ada beberapa metode, sebagai berikut:

\begin{tabular}{|l|l|l|l|}
\hline NO. & PERMASALAHAN & SOLUSI PERMASALAHAN & $\begin{array}{l}\text { METODE } \\
\text { PELAKSANAAN }\end{array}$ \\
\hline 1. & $\begin{array}{l}\text { Cara membuat cairan } \\
\text { desinfektan yang aman } \\
\text { dan ramah lingkungan }\end{array}$ & $\begin{array}{l}\text { Dari permasalahan yang ada kami } \\
\text { mencoba berkoordinasi dengan } \\
\text { mitra kami, dan kami mendapatkan } \\
\text { informasi cara membuat } \\
\text { desinfektan yang aman dan ramah } \\
\text { lingkungan, dengan bahan bahan } \\
\text { dan komposisi yang sudah sesuai } \\
\text { pencampuran bahan tersebut } \\
\text { dengan } \\
\text { secukupnya sesuai takaran } \\
\text { dari desinfektan yang akan } \\
\text { dibuat. }\end{array}$ \\
\hline 2. & $\begin{array}{l}\text { Waktu dengan mitra yang } \\
\text { tidak sesuai sehingga } \\
\text { perlu dikoordinasikan }\end{array}$ & $\begin{array}{l}\text { Waktu adalah masalah yang sangat } \\
\text { menjadi penentu akan kegiatan } \\
\text { PKM ini, maka dari itu koordinasi }\end{array}$ & $\begin{array}{l}\text { Mencocokan jadwal kegiatan } \\
\text { kami dengan waktu kosong } \\
\text { atau waktu senggang mitra }\end{array}$ \\
\hline
\end{tabular}




\begin{tabular}{|c|c|c|c|}
\hline & lebih lanjut. & $\begin{array}{l}\text { dan menyesuaikan waktu dengan } \\
\text { mitra adalahjalan keluar dari } \\
\text { masalah ini agar semua rencana } \\
\text { tetap berjalan dengan seharusnya. }\end{array}$ & $\begin{array}{l}\text { PWPM DKI Jakarta, sehingga } \\
\text { akhirnya program yang ada } \\
\text { dapat berjalan sesuai rencana } \\
\text { yang sudah kami buat tanpa } \\
\text { harus mengurangi jadwal dari } \\
\text { PKM yang sudah tersusun. }\end{array}$ \\
\hline 3. & $\begin{array}{l}\text { Mencari bahan - bahan } \\
\text { dasar dengan prosentasi } \\
\text { kandungan } \\
\text { kebutuhan, } \\
\text { berikut: } \\
\text { - } \mathrm{HCL}\left(\mathrm{H}_{2} \mathrm{O}_{2}\right) \\
\text { - Chlorine Granular Tcca } \\
90 \% \\
\text { - Ethanol } 96 \%\end{array}$ & $\begin{array}{l}\text { Bahan-bahan yang kami butuhkan } \\
\text { tidak semua mudah untuk } \\
\text { didapatkan diluaran karena } \\
\text { kandungannya yang menyebabkan } \\
\text { sulit dan kekhawatiran } \\
\text { disalahgunakan. Namun dengan } \\
\text { kepakaran yang dimiliki mitra } 1 \\
\text { kami sehingga link untuk membeli } \\
\text { bahan-bahan tersebut dapat diatasi. }\end{array}$ & $\begin{array}{l}\text { Dengan link dari mitra } 1 \text { kami } \\
\text { PWPM DKI Jakarta, bahan } \\
\text { bahan produki desinfektan } \\
\text { bisa kami dapatkan dengan } \\
\text { kadar serta kandungan sesuai } \\
\text { dengan yang diharapkan. }\end{array}$ \\
\hline
\end{tabular}

\subsection{Tahapan Pelaksanaan}

Tahapan awal dari kegiatan ini adalah kami melakukan observasi ke pihak mitra dengan beberapa kegiatan hingga Tahapan Laporan Akhir, sebagai berikut:

a. Kunjungan ke PCM Kramat Jati dan PWPM DKI Jakarta

b. Mendapatkan bimbingan dari PCM Kramat Jati dan PWPM DKI Jakarta tentang apa yang akan menjadi tema dalam PKM kami kali ini.

c. Mengajukan Proposal Kegiatan PKM di STIH Iblam Kramat Raya,Jakarta Pusat

d. Membuat Desinfektan adalah arahan dari mitra 1 PWPM DKI Jakarta.

e. Melakukan Baksos dilingkungan sekitar mitra berdomisili yang diwakili oleh Mitra 2 PCM Kramat Jati.

f. Laporan Harian bentuk pertanggungjawaban kepada ketua PKM.

g. Laporan Akhir Kegiatan di PCM Kramat Jati.

\section{Gambaran Metode Pelaksanaan Kegiatan PKM}

Metode pelaksanaan kami buat untuk mencapai tujuan dari Kegiatan Pengabdian Kepada Masyarakat dalam mengatasi masalah masyarakat untuk menghadapi kondisi new normal, yang kami lakukan sebagai Tim Pengabdian Kepada Masyarakat adalah dengan menyumbang Produk Disenfektan yang telah dibuat bersama mitra PWPM DKI Jakarta yang nantinya akan dibantu oleh mitra 2 kami yaitu PCM Kramat Jati untuk dibagikan kepada masyarakat sekitar mitra kami berdomisili.

\section{Jadwal Pengabdian Masyarakat}

\subsection{Kegiatan Pertama/Kamis ,13 November 2020}

\section{Bimbingan PKM (Ketua PKM Dr. Marjan Miharja, S.H.,M.H.)}

Pengarahan Kegiatan PKM, cara pembuatan proposal PKM dan pengenalan mitra PCM Kramat Jati dan PWPM DKI Jakarta untuk kegiatan PKM 
Dokumentasi:
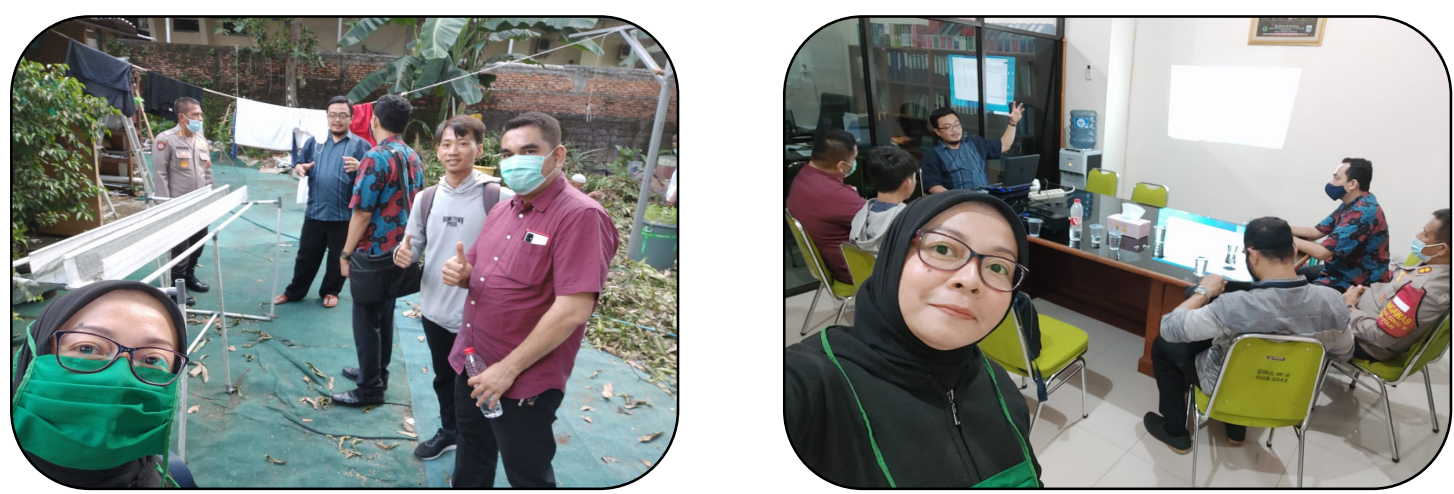

3.2 Kegiatan Kedua/Senin, 16 November 2020

\section{Bimbingan PKM}

(Ketua PKM Dr. Marjan Miharja, S.H.,M.H./ Apt. Guntur S.R, S.,Si.)

Pengarahan tentang kemitraan dan produk yang dihasilkan, menjelaskan tentang luaran wajib yang akan dihasilkan.

Dokumentasi:
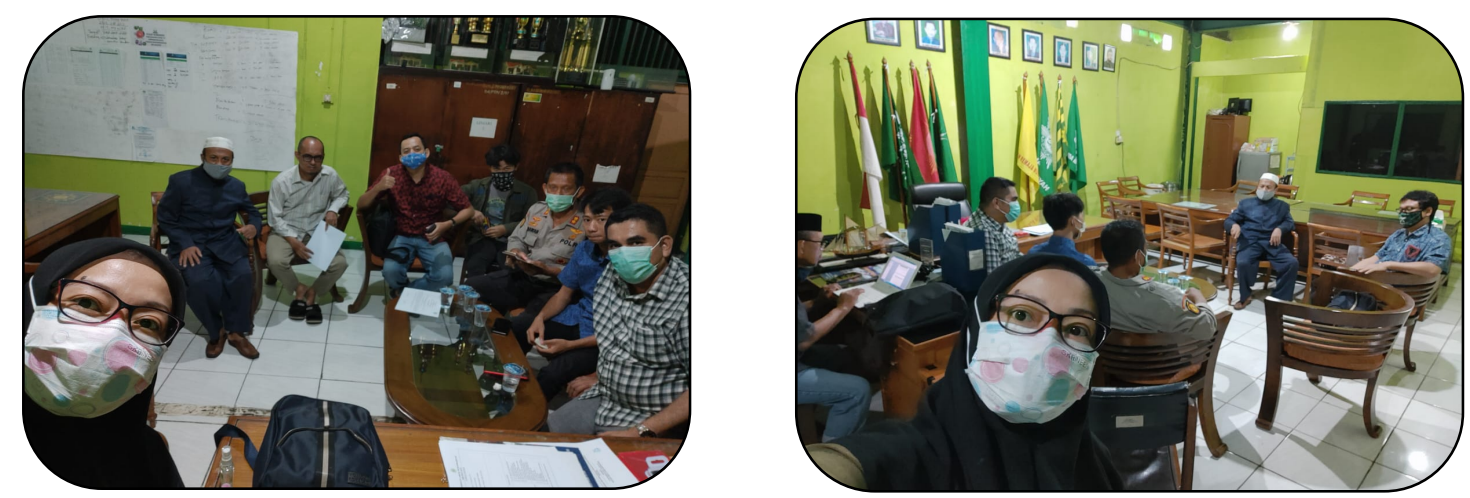

\subsection{Kegiatan Ketiga}

Bimbingan PKM/Senin, 23 November 2020

(Ketua PKM Dr. Marjan Miharja, S.H.,M.H./ PWPM DKI Jakarta Apt. Guntur S.R, S.,Si.)

Pengarahan tentang tahapan pembuatan Desinfektan yang aman dan ramah lingkungan serta penjelasan tentang komposisi produk.

Dokumentasi:
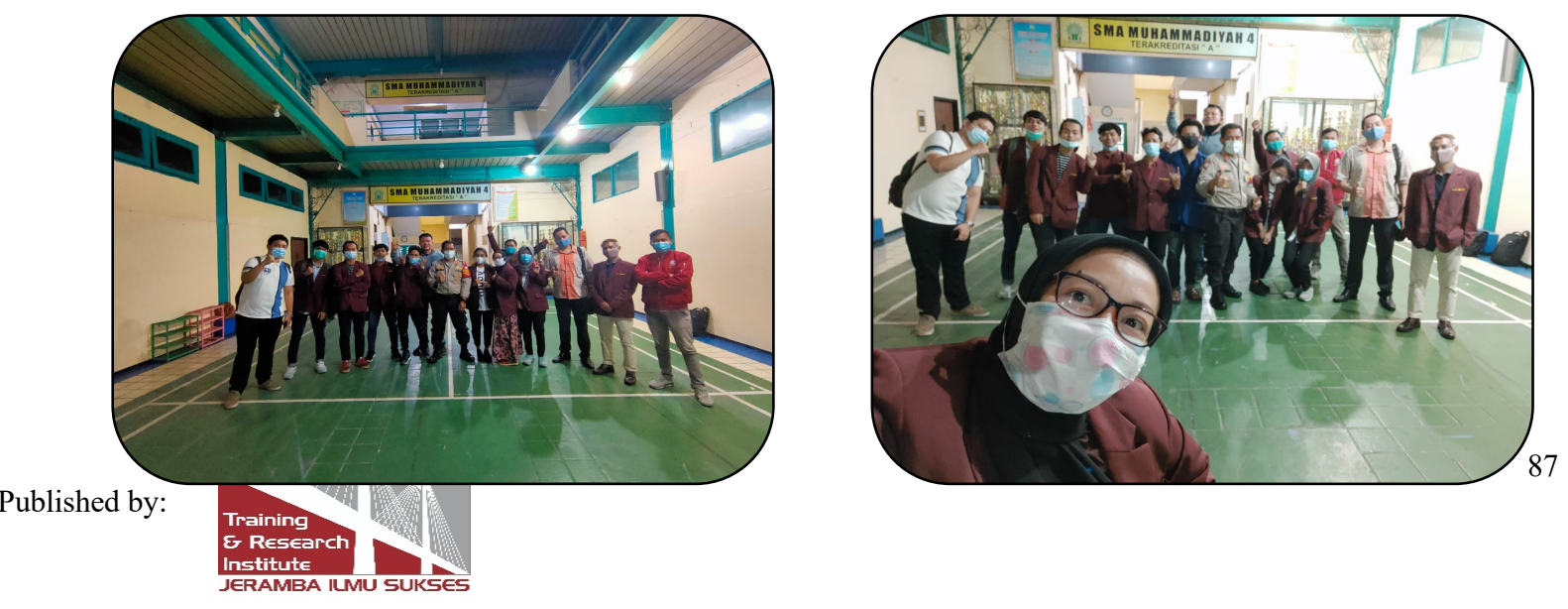

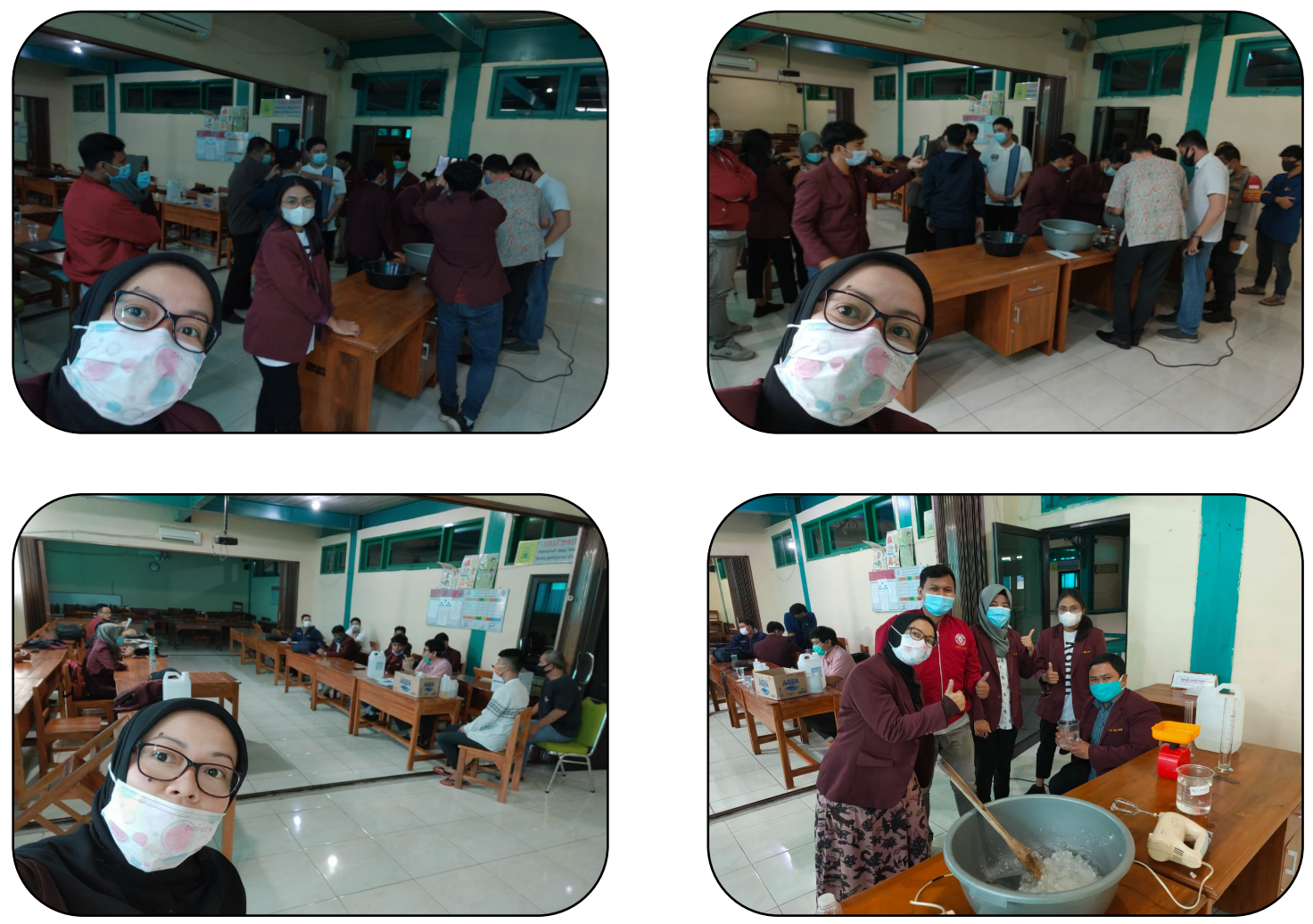

\subsection{Kegiatan keempat/Selasa, 24 November 2020}

Pengajuan Proposal PKM/Bertempat di STIH IBLAM dan diuji oleh dosen dan Ketua PKM STIH IBLAM

\subsection{Kegiatan Kelima/Kamis, 26 November 2020}

Bimbingan Pembuatan Produk PKM

(Ketua PWPM DKI Jakarta Apt. Guntur S.R , S.,Si.)

Pembuatan produk desinfektan dengan kapasitas 500 liter, yang akan dipandu oleh mitra PWPM DKI Jakarta.

Dokumentasi:
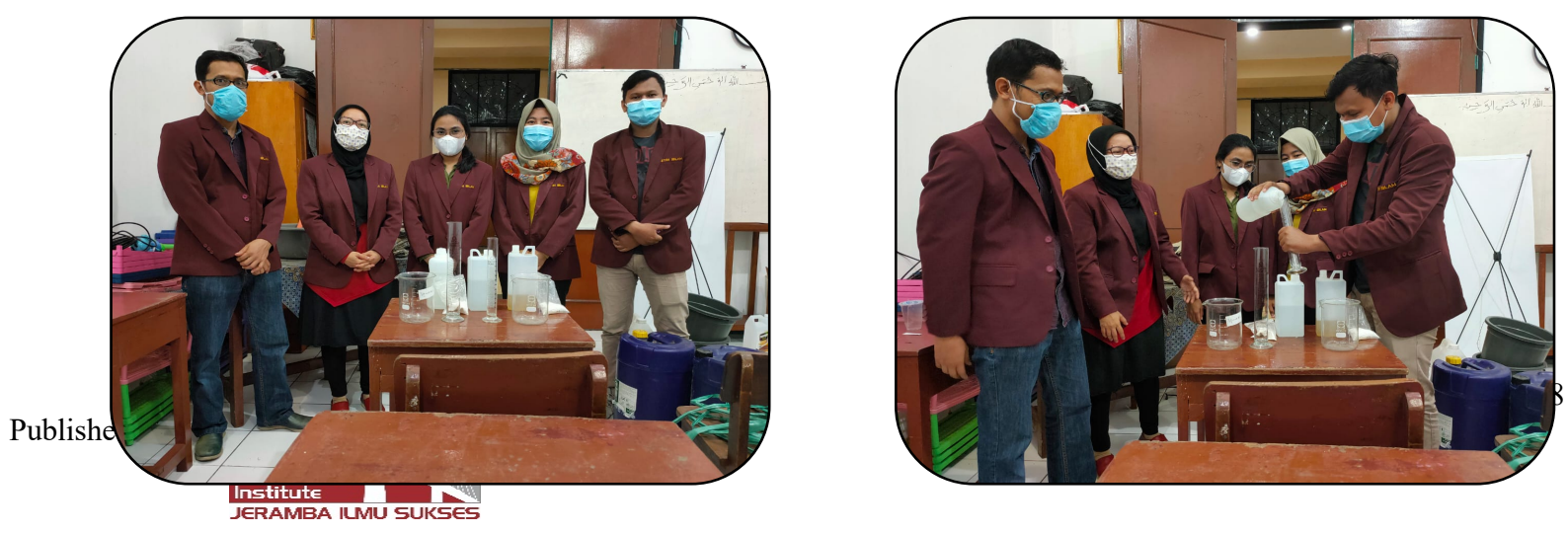

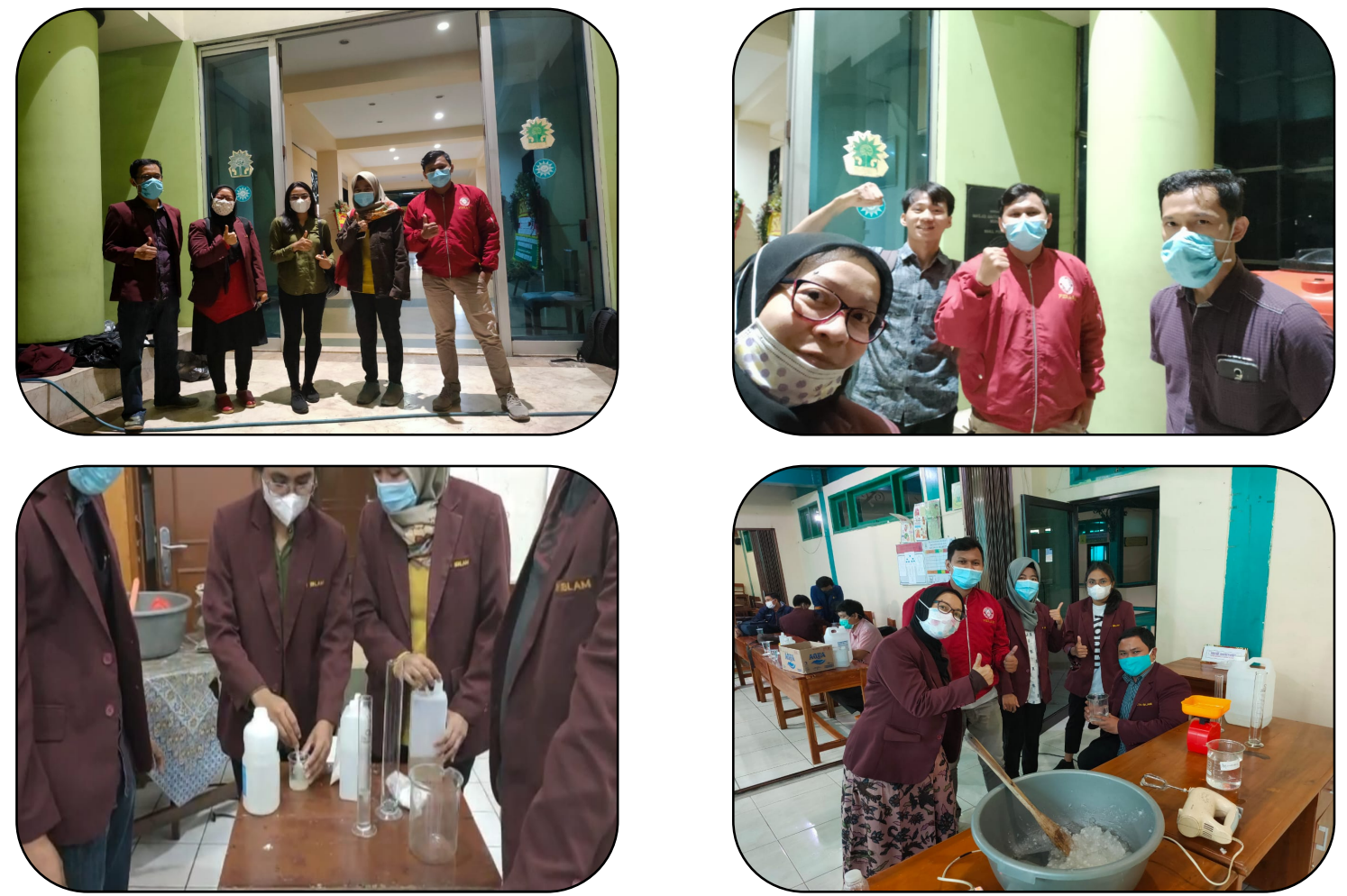

\subsection{Kegiatan Keenam}

Laporan Harian kegiatan PKM

Laporan Harian kegiatan PKM ini akan kami buat dalam bentuk jurnal yang akan kami terbitkan di JNPM ( http://journal.jis-institute.org/index.php/jnpm ), serta Video yang akan kami upload di channel youtube kampus kami STIH Iblam, serta kegiatan PKM yang akan beritakan dimedia Sindo Online dan Republika dan laporan Harian yg akan kami laporkan kepada Ketua PKM STIH IBLAM

\subsection{Kegiatan Ketujuh}

Seminar Laporan Akhir kegiatan PKM

Kami akan memaparkan laporan kegiatan selama PKM di acara seminar yang akan diselenggarakan ditempat mitra kami yaitu PCM Kramat Jati, Jakarta Timur, DKI Jakarta.

\section{Uraian Tugas (Job Description) Ketua, Anggota, dan Mahasiswa}

\begin{tabular}{|l|l|l|l|}
\hline NO. & NAMA & JABATAN & URAIAN TUGAS \\
\hline 1. & $\begin{array}{l}\text { Dr. Marjan Miharja, } \\
\text { S.H.,M.H. }\end{array}$ & Ketua PKM & $\begin{array}{l}\text { Dosen Ketua: } \\
\text { Memberikan panduan, tata cara serta } \\
\text { aturan PKM di STIH Iblam }\end{array}$ \\
\hline
\end{tabular}




\begin{tabular}{|c|c|c|c|}
\hline & & & $\begin{array}{l}\text { - Menginformasikan tentang kemitraan } \\
\text { untuk kegiatan PKM ini } \\
\text { - Bertanggungjawab sepenuhnya tentang } \\
\text { program PKM STIH IBLAM ini. }\end{array}$ \\
\hline 2. & $\begin{array}{l}\text { Wiend Sakti Myharto, } \\
\text { S.H L.LM }\end{array}$ & Anggota PKM & $\begin{array}{l}\text { Dosen Anggota: } \\
\text { - Membantu ketua PKM } \\
\text { mengarahkanmembimbing Tim } \\
\text { Pengabdian untuk kelancaran kegiatan } \\
\text { PKM ini. }\end{array}$ \\
\hline 3. & Yastuty Handalya & $\begin{array}{l}\text { Ketua } \\
\text { Pengabdian }\end{array}$ & $\begin{array}{l}\text { Ketua Pengabdian: } \\
\text { - Mengatur dan mengkoordinasikan } \\
\text { kegiatan PKM kepada anggota } \\
\text { pengabdian } \\
\text { - Berkoordinasi dengan Ketua PKM } \\
\text { untuk semua kegiatan PKm dan } \\
\text { meminta arahan untuk kegiatan. } \\
\text { - Koordinasi dengan LPPM kampus guna } \\
\text { kebutuhan administrasi kegiatan PKM } \\
\text { - Berkoordinaasi dengan Mitra PWPM } \\
\text { DKI Jakarta guna rencana produk yang } \\
\text { akan dibuat } \\
\text { - mengatur waktu jadwal serta mengatur } \\
\text { kelengkapan data proposal, laporan } \\
\text { Haruan dan Laporan Akhir }\end{array}$ \\
\hline 4. & Jean Magtel Pah & $\begin{array}{l}\text { Bendahara } \\
\text { Pengabdian }\end{array}$ & $\begin{array}{l}\text { - Membantu ketua dalam mengelola } \\
\text { keuangan kelompok } \\
\text { - Membuatlaporankeluar masuk kas } \\
\text { kelompok } \\
\text { - Membantu pelaksanaan pembuatan } \\
\text { proposal } \\
\text { - Membantu pembuatan produk } \\
\text { desinfektan } \\
\text { - Membantu ketua membuat Laporan } \\
\text { Akhir }\end{array}$ \\
\hline 5. & $\begin{array}{l}\text { Mayang Maharani } \\
\text { Yahya Bayan }\end{array}$ & $\begin{array}{l}\text { Sekertaris } \\
\text { Pengabdian }\end{array}$ & $\begin{array}{l}\text { - Membantu ketua dalam proses } \\
\text { pembuatan proposal } \\
\text { - MembuatLaporan Harian }\end{array}$ \\
\hline
\end{tabular}




\begin{tabular}{|c|c|c|c|}
\hline & & & $\begin{array}{l}\text { - Membantu ketua membuat Laporan } \\
\text { Akhir } \\
\text { - Membantu pembuatan produk } \\
\text { desinfektan } \\
\text { - Membantu serah terima produk ke } \\
\text { Mitra 1 }\end{array}$ \\
\hline 6. & Emil Salim & $\begin{array}{l}\text { Anggota } \\
\text { Pengabdian }\end{array}$ & $\begin{array}{l}\text { - Membantu ketua dalam proses } \\
\text { pembuatan proposal } \\
\text { - Memberikan masukan atas kegiatan } \\
\text { yang sudah dilakukan setiap hari. } \\
\text { - Membantu ketua membuat Laporan } \\
\text { Akhir } \\
\text { - Membantu pembuatan produk } \\
\text { desinfektan } \\
\text { - Membantu serah terima produk ke } \\
\text { Mitra 1. }\end{array}$ \\
\hline 7. & Anggoro Hendrawan & $\begin{array}{l}\text { Anggota } \\
\text { Pengabdian }\end{array}$ & $\begin{array}{l}\text { - Membantu ketua dalam proses } \\
\text { pembuatan proposal } \\
\text { - Memberikan masukan atas kegiatan } \\
\text { yang sudah dilakukan setiap hari. } \\
\text { - Membantu ketua membuat Laporan } \\
\text { Akhir } \\
\text { - Membantu pembuatan produk } \\
\text { desinfektan } \\
\text { - Membantu serah terima produk }\end{array}$ \\
\hline 8. & Ryan Hidayat & $\begin{array}{l}\text { Anggota } \\
\text { Pengabdian }\end{array}$ & $\begin{array}{l}\text { - Membantu ketua dalam proses } \\
\text { pembuatan proposal } \\
\text { - Memberikan masukan atas kegiatan } \\
\text { yang sudah dilakukan setiap hari. } \\
\text { - Membantu ketua membuat Laporan } \\
\text { Akhir } \\
\text { - Membantu pembuatan produk } \\
\text { desinfektan } \\
\text { - Membantu serah terima produk }\end{array}$ \\
\hline
\end{tabular}




\section{Referensi}

Durrotun Munafiah., \& Risky Puji Wulandary., (2020, November) SEMON (SEMINAR ONLINE NASIONAL) KEBIDANAN ASUHAN PSIKIS DAN FISIK PADA PERSALINAN NORMAL OLEH PRAKTIK BIDAN MANDIRI (PMB) DI MASA COVID-19. Jurnal Pengabdian Masyarakat Sasambo, 2715-0496.(jkp.poltekkes-mataram.ac.id)

Marianus Mantovanny Tapung, Max Regus, Marsel Ruben Payong, Stefanus Turibus Rahmat, Frederikus Maigahoaku Jelahu., (2020) BANTUAN SOSIAL DAN PENDIDIKAN KESEHATAN BAGI MASYARAKAT PESISIR YANG TERDAMPAK SOSIAL-EKONOMI SELAMA PATOGENESIS COVID-19 DI MANGGARAI. Jurnal Pengabdian Masyarakat, 1858-3571, 2580-9628.(journal.uinmataram.ac.id)

Intruksi Presiden Nomor 4 tahun 2020 tentang. "Tentang refocussing kegiatan, realokasi anggaran serta pengadaan barang dan jasa dalam rangka percepatan penanganan Corona Virus Disease 2019 (COVID-19)".

Perubahan Kedua Undang-Undang Dasar 1945. Kesehatan ditegaskan sebagai bagian dari hak asasi manusia. DalamPasal $28 \mathrm{H}$ ayat (1) dinyatakan, bahwa: "Setiap orang berhak hidup sejahtera lahir dan batin, bertempat tinggal, dan mendapat lingkungan hidup yang baik dan sehat serta berhak memperoleh pelayanan kesehatan."

Undang-undang Nomor 36 Tahun 2014. Tentang Tenaga Kesehatan namun saat ini belum ada peraturan pelaksanaan dan petunjuk teknis Undang-undang Tenaga kesehatan dan undang-undang lainnya yang mengatur tentang perlindungan hukum dan keselamatan kerja bagi Tenaga kesehatan.

Undang-Undang Nomor 6 Tahun 2018. Tentang Kekarantinaan Kesehatan merupakan wewenang absolutPemerintah Pusat.

Peraturan Pemerintah No. 21 Tahun 2020. Tentang Pembatasan Sosial Berskala Besar dalam rangka Percepatan Penanganan Corona Virus Disease (COVID-19). 


\section{Lampiran}

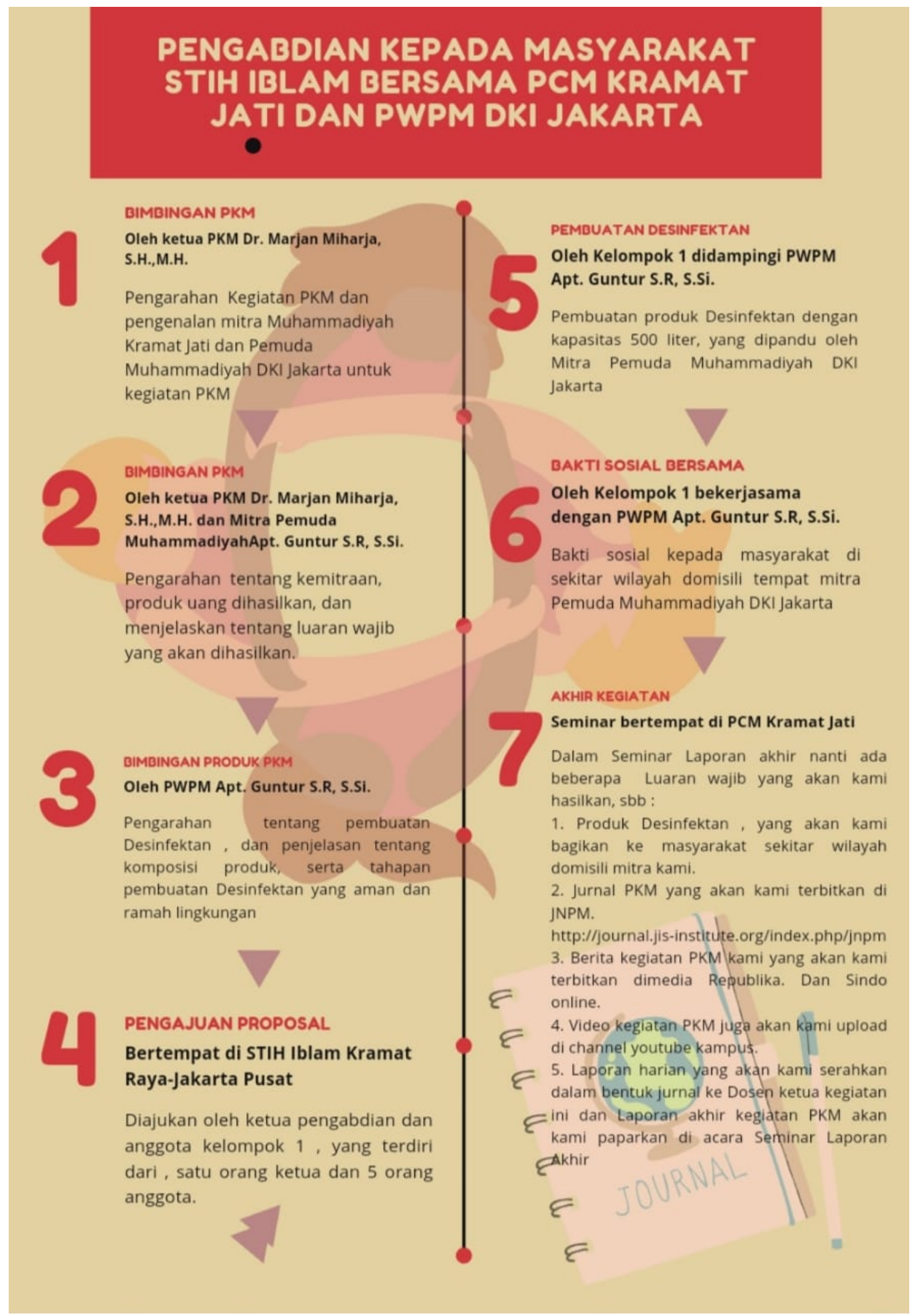

Published by: 